\title{
VIOLENCE AND POLITICAL PROTEST IN MING AND QING CHINA
}

\author{
REVIEW AND COMMENTARY ON RECENT RESEARCH
}

Thomas T. Meadows, an experienced British diplomat in China during the nineteenth century and author of The Chinese and Their Rebellions, wrote: "Of all nations that have attained a certain degree of civilization, the Chinese are the least revolutionary and the most rebellious."1 Meadows had ample opportunity to make such a remark since he was witness to some of China's fiercest rebellions, those committed by the Taipings, the Nien and Moslem groups during the time of his tour. These revolts, although mass-based and widespread, were put down with particular ferocity by the Qing monarchy. Meadows's remark directs attention to the delicate question of when does a rebellion become a revolution? In the case of these movements, they did not become revolutions because there was no transformation either in the structure of Chinese society or in the system of political power. These incidents may have been "revolutionary situations", but they did not have "revolutionary outcomes".

It is the violence and political protest which emerge in these "revolutionary situations", however, which have most stimulated the interest of Chinese historians. Traditional writers, responsible for composing the twenty-four dynastic histories, have regarded both these phenomena as part of the "dynastic cycle". ${ }^{2}$ Successive political regimes repeated a repetitious story: a spirited founding usually under violent circumstances, a period of strong and effective central-government control, then a long decline during which violence and political protest once again become

1 Th. T. Meadows, The Chinese and Their Rebellions, Viewed in Connection with Their National Philosophy, Ethics, Legislation, and Administration (London, 1856), p. 25. Italics in the original.

2 For information on the dynastic cycle, see J. Fairbank and E. Reischauer, China: Tradition and Transformation (Sydney, 1979), pp. 70-75; Kao Yu-kung, "Source Materials on the Fang La Rebellion", in: Harvard Journal of Asiatic Studies, XXVI (1966), pp. 211-40; Yuji Muramatsu, "Some Themes in Chinese Rebel Ideologies", in: The Confucian Persuasion, ed. by A. F. Wright (Stanford, 1960), pp. 241-67; V. Shih, "Some Chinese Rebel Ideologies", in: T'oung Pao, XLIV (1956), pp. 150-226. 
frequent, and finally total collapse, with much suffering, destruction of property, and loss of life. Incorporated into this notion of the dynastic cycle was a retributive element. Pushed to the extreme, this aspect of the cycle suggested that a lax ruler deserved to lose his power and the "people" had the "right" to rebel, and engage in violence. ${ }^{3}$ A ruler's political competence or negligence was judged by the well-being of his subjects. If peasants rebelled or other groups protested, then the ruler was responsible for bad government. In other words, political rebellions seemed to prove that the Emperor and his family were no longer competent, and that the dynastic cycle had reached its term.

Unfortunately, when Western sinologists first began to write about Chinese history, they too adapted the concept of dynastic cycle, and consequently their understanding of violence and political protest was handicapped. ${ }^{4}$ It is clear that until recently, for both Chinese and Western historians alike, China's political history took precedence over the fundamental dynamics behind its economic, social and cultural development. ${ }^{5}$ Where these histories went beyond the political narrative, they still only could cite problems of China's fiscal conditions, government organization or military strengths and weaknesses in the context of the dynastic cycle. Violence and political protest were viewed here as symbolic of the last phase of decline in a seemingly static frozen political order.

In many ways the study of violence and political protest in Chinese history has not fared much better under Marxist scholarship either. In the process of redressing the "wrongs" of an "elitist history" written by Confucian historians during the Empire, Chinese Communist historians since 1949 have focused on class struggle. Peasants and people, economic exploitation and political oppression are central concerns but, on the other hand, violent movements whatever the variation in form, degree or geographical location are all seen, until recently, as part of general class

3 The basis of this argument originated in the fourth century $\mathrm{BC}$ in the writings of the philosopher Meng K'e, better known as Mencius. See Mencius, transl. by D. C. Lau (Harmondsworth, 1970), especially Book IV, Pt A.

${ }^{4}$ See the introduction in The Pattern of Chinese History: Cycles, Development, or Stagnation?, ed. by J. Meskill (Lexington, 1965).

5 An excellent critique on the predominance of Chinese political history is in A. F. Wright, "The Study of Chinese Civilization", in: Journal of the History of Ideas, XXI (1960), pp. 233-55. Further criticism on current writing about Chinese history, especially since the mid 1960's, may be seen in Th. Metzger and R. Myers, "Sinological Shadows: The State of Modern China Studies in the US", in: The Australian Journal of Chinese Affairs, No 4 (1980), pp. 1-34. For a critical and penetrating analysis of popular movements in Chinese history, refer to the excellent article by F. Wakeman, Jr, "Rebellion and Revolution: The Study of Popular Movements in Chinese History", in: Journal of Asian Studies, XXXVI (1976-77), pp. 201-37. 
struggle. ${ }^{6}$ Mao Zedong's own studies of mass movements in Chinese history led him to conclude that they were "without parallel in world history". ${ }^{7}$ For these Communist historians, the important point is that understanding social disorder in the past should provide inspiration for class struggle in the present. What is relevant is the general idea of opposition, not understanding the specific conditions which generated violence and political protest.

Some observers may recognise a certain similarity here between the dynastic-cycle concept and Marxist views whereby history is used as a tool by those in authority "to legitimise the present by appeals to the past". 8 Neither viewpoint, however, has gone without critics, and when we approach the subject of violence and political protest in the Ming (1368-1644) and Qing (1644-1911) dynasties, we see a whole new range of studies which genuinely attempt to overcome past limitations. For example, many historians, no longer satisfied with the traditional interpretation of the Qing as simply a replication of the Ming, have begun to demonstrate that the entire period from the 1550's to at least 1780 constitutes a coherent whole. ${ }^{9} 1644$ is not a critical terminal. Historians currently writing in the People's Republic of China downplay "the revolutionary nature" of certain mass movements, once noted for their radical significance. ${ }^{10}$ Chinese historians of varying persuasions are beginning to look "toward the components of collective action", in the words of the foremost historian of violence in the West, Charles Tilly, not just toward the rebellion or revolution itself. No doubt part of this re-evaluation is due to the increasing availability of archival sources both in Taiwan and the

6 For a thorough introduction to Chinese Communist historiography on peasant rebellions before 1966 at the start of the Cultural Revolution, see J. P. Harrison, The Communists and Chinese Peasant Rebellions (New York, 1969), especially Pt I. Between the 1950's and 1966, a few eminent historians voiced discontent over the revolutionary aims of peasants' role in class struggle. They would write, as did Jian Bozan in 1961, that peasant rebels opposed landlords, but not landlordism. These historians were, however, a definite minority. See Harrison, pp. 215-24.

7 Mao Tse-tung, Selected Works (Peking, 1961), III, p. 76.

${ }^{8}$ H. Kahn and A. Feuerwerker, "The Ideology of Scholarship: China's New Historiography", in: History in Communist China, ed. by A. Feuerwerker (Cambridge, Mass., 1968), p. 5.

9 See the Preface to From Ming to Ch'ing: Conquest, Region, and Continuity in Seventeenth-Century China, ed. by J. D. Spence and J. E. Wills, Jr (New Haven, 1979), and F. Wakeman, $\mathrm{J}_{\mathrm{r}}$, "The Evolution of Local Control in Late Imperial China", in: Conflict and Control in Late Imperial China, ed. by F. Wakeman, Jr, and C. Grant (Berkeley, 1975), pp. 1-25.

10 Kwang-Ching Liu, "World View and Peasant Rebellion: Reflections on Post-Mao Historiography", in: Journal of Asian Studies, XL (1980-81), pp. 295-326. 
PRC and the growing sophistication of research methodology, including the application of the computer. ${ }^{11}$

In this paper I shall try to evaluate some of the more outstanding recent examples of critical writing which discuss violence and political protest during the Ming and early Qing periods, either directly or indirectly, and attempt to make a few preliminary remarks about how these new studies may affect our understanding of Chinese history.

\section{Late-Ming society and urban crowd actions (1550-1626)}

Some of the most interesting new work on violence and political protest has concentrated on urban riots occurring from the 1550's onward. By the mid sixteenth century Chinese society consisted of two main groups: the ruling class, including the Emperor, his officials and eunuchs, and the common people, including peasant farmers, merchants and artisans. ${ }^{12} \mathrm{~A}$ third group or middle layer of society, composed of literate but powerless intellectuals often played a role in these riots. Jobless lower-degree holders, monks, priests, and such pseudo-intellectuals as fortune tellers and sorcerers would lend their leadership when the occasion might arise. While most urban disturbances involved workers, artisans, and labourers from factories, potteries and weaving establishments, as well as the unemployed, it was not unknown for this middle strata to become involved. When, for example, in 1593 a popular local-government officer was transferred from Sôngjiang to another location on the advice of local powerful families who felt threatened by him, townsmen under the leadership of shengyuan, the lowest-

11 To date, the most thorough and extensive coverage of related materials on violence and political protest in Chinese history may be found in Ssu-yü Teng, Protest and Crime in China. A Bibliography of Secret Associations, Popular Uprisings, Peasant Rebellions (New York, 1981). This volume contains entries on 4,000 articles, books, reviews, dissertations, local gazetteers, unpublished papers and rare editions in Chinese, Japanese, English, French, German, Russian, Dutch and Korean in collections in the United States, the People's Republic of China, Taiwan, Hong Kong, Japan and Europe. See also the chapter "The Study of Peasant Uprisings" in Ming and Qing Historical Studies in the People's Republic of China, ed. by F. Wakeman, Jr (Berkeley, 1980), pp. 104-12, and C. K. Yang, "Some Preliminary Statistical Patterns of Mass Actions in Nineteenth-Century China", in: Conflict and Control, op. cit., pp. 174-210, for application of the use of the computer to mass movements.

12 Scholars have conventionally termed part of this ruling class in China as "gentry", but for reasons of clarification it would seem best not to use this expression here. The distinction is made in this paper between the local elite, those possessing bureaucratic degrees and/or landed wealth, and the court elite, those members of the bureaucracy working in court circles with the Emperor in Peking. For further explanation see $\mathrm{F}$. Wakeman, Jr, The Fall of Imperial China (New York, 1975), pp. 19-37, and H. Zurndorfer, "The Hsin-an ta-tsu chih and the Development of Chinese Gentry Society", in: T'oung Pao, LXVII (1981), pp. 154-215. 
degree holders, began to form a crowd and protested. At the height of the movement some 10,000 people gathered; it took three weeks before imperial troops could quell them. ${ }^{13}$

Urban crowd actions in Ming and Qing China have not been studied much, but it is clear from official records that during the seventeenth and eighteenth centuries at least fifty serious incidents occurred in some of the most important cities of Central China where the commercial wealth of the Empire lay. ${ }^{14}$ The expanding silk and cotton industries, the growth of inter-regional trade, accompanied by the outflow of Chinese silk and porcelain and the inflow of silver, formed the background to a society inundated with wealth and sophistication. ${ }^{15}$ While it is often assumed that the administrative system of the Chinese bureaucracy never allowed for an independent order, so that, for example, Chinese merchants never had charters of autonomy, ${ }^{16}$ this does not mean that the urban population was passive and docile. The frequency of violent occurrences suggests that unrest was just as much a part of urban life as prostitution, theater-going and gastronomy were by the late sixteenth century. ${ }^{17}$

The characteristics of late-Ming riots are simple enough to recognize. None of these riots was consistently over one specific issue, such as lack of food, but they display a variety of causes: opposition to a silk tax, to the idiosyncrasies of an official, to administrative malfaisance, to the misdeeds of a eunuch who might be in control of a specific industry. As direct representatives of the imperial family, eunuchs quite often took advantage

13 Mentioned in Tsing Yuan, “Urban Riots and Disturbances”, in: From Ming to Ch'ing, op. cit., pp. 277-320.

${ }_{14}$ For a detailed list of these cities and the years of disturbances, see Sakai Tadao, Chugoku Zenshô no kenkyû (A Study of Chinese Morality Books) (Tokyo, 1960), pp. 152-56.

15 Excellent descriptions and analyses of the late-Ming economy are in W. S. Atwell, "Notes on Silver, Foreign Trade, and the Late Ming Economy", in: Ch'ing-shih Wen-t'i, III, No 8 (1977), pp. 1-33, and the same author's "International Bullion Flows and the Chinese Economy circa 1530-1650", in: Past \& Present, No 95 (1982), pp. 68-90. For a stimulating discussion on the implications of a growing Ming economy, see R. Myers,

"Some Issues on Economic Organization during the Ming and Ch'ing Periods: A Review Article", in: Ch'ing-shih Wen-t'i, III, No 2 (1974), pp. 77-93.

16 See E. Balazs, "The Birth of Capitalism in China", in Chinese Civilisation and Bureaucracy (New Haven, 1964), pp. 34-54, and compare M. Weber, The Religion of China (New York, 1951).

17 Major violent urban incidents occurred in 1567, 1571, 1582, 1592, 1593, 1596, 1597, $1599,1600,1601,1602,1603,1604,1607,1626,1628$ and 1641. On the richness and sophistication of urban life in the late Ming see F. W. Mote, "A Millennium of Chinese Urban History: Form, Time, and Space Concepts in Soochow", in: Rice University Studies, LIX (1973), pp. 35-65, and the same author's essay on gastronomy during the Ming in Food in Chinese Culture, ed. by K. C. Chang (New Haven, 1977), ch. 5. 
of their favored position by having themselves appointed the head of a specific industry, and then imposing exceedingly harsh demands on those involved in that industry. ${ }^{18}$ Violent action itself would take the form of property destruction and assault, or at least attempted assault, on those in authority. Most of the riots were also dependent on mass spontaneity of the moment. Until the above-mentioned third group took over the leadership, there was a low level of discipline and organization.

Also, in the late Ming period the common people might occasionally find that a riot was led by members of the local elite. In a weavers' riot in 1601 and another in 1626 artisans, merchants and labourers joined with the Suzhou local elite to resist exactions and arbitrary demands of a eunuch. ${ }^{19}$ It has been suggested that the joint participation of crowds of townspeople and leading members of the local elite may be symptomatic of a growing sense of urban identity in the late Ming. Large numbers of wealthy extended families with a desire for a more sophisticated life style began to move from their landholdings in the countryside to take up residence in cities in the second half of the sixteenth century. This "joining of forces" may be connected with a new type of political moralism which evolved in an urban setting. ${ }^{20}$ The relationship between the Donglin Party (literally, "Eastern Party"), whose name was taken from a scholastic academy at Wushi on the lower Yangze, and urban commercial interests is relevant. Originally led by a dozen scholar-ex-officials, most of whom had been dismissed during factional controversies at Court in Peking, Donglin members lectured at affiliated academies nearby, and soon spread their influence among scholars and officials in the cities of Jiangsu and Zhejiang in a moral crusade to reassert the traditional principles of Confucian conduct. They denounced various holders of power, both high-placed bureaucrats and eunuchs, for misusing their influence in violation of Confucian principles. By 1630 various off-shoots of the party, the Yingshe and the Fushe, were also in operation, gaining hundreds of adherents. ${ }^{21}$ Calling for relaxed government restraints on industry, the curbing of official sanctions, and the elimination of eunuchs as tax commissioners,

18 On eunuch involvement in Chinese economic life, refer to $\mathrm{H}$. Zurndorfer, "Chinese Merchants and Commerce in Sixteenth Century China", in: Leyden Studies in Sinology, ed. by W. Idema (Leiden, 1981), pp. 75-86. Compare Ch. Hucker, "Su-chou and the Agents of Wei Chung-hsien", in Two Studies on Ming History (Ann Arbor, 1971).

19 Yuan, "Urban Riots and Disturbances", loc. cit., p. 310.

20 J. Dennerline, The Chia-ting Loyalists: Confucian Leadership and Social Change in Seventeenth Century China (New Haven, 1981).

21 W. Atwell, "From Education to Politics: The Fu She", in: The Unfolding of NeoConfucianism, ed. by W. T. Debary (New York, 1975), pp. 333-69. Also J. Meskill, Academies in Ming China: A Historical Essay (Tucson, 1982). 
Donglin members and their associates showed ground for common action with mercantile interests. Moreover, many of the academies where these adherents gathered were financially supported by mercantile-based groups. The fact that large numbers of educated but disgruntled men gathered in urban centers to study at institutions which were spousing ideals not necessarily practised by the late-Ming government was in itself potentially trouble-making. Thus a kind of passive alliance between a small segment of the local elite, urban workers and the third layer of society was brought together through a mutual desire to redress economic grievances and establish better government.

The role of violence and political protest under these circumstances is clear. It is not part of a search for a new political order, but rather an improvement of the existing one. When the urban populace challenged the Ming government on several occasions, it did not seek much beyond the elimination of a certain number of immediate abuses, but the fact that part of the "establishment", for whatever reasons of its own, and however seldom, sided with the protesters on occasion is significant. To the extent that the contenders in late-Ming China were dependent on commonplace origins for their association necessarily affected the outcome of their collective actions. The collective violence in which they engaged was localized, more often than not unco-ordinated, and in the long run ineffective. However, one should not see these events as a simple symbol of dynastic decline. As recent scholarship on urban riots has demonstrated, these events continued throughout the early Qing period. According to one preliminary analysis of the market strikes and food protests of the eighteenth century, they were put down with much greater ferocity than those occurring earlier. ${ }^{22}$ This suggests a reorganization of the forces of repression, and not necessarily a change in the factors which initiated the riots to begin with.

\section{The peasant rebellions of the 1630's and 1640's and the Qing conquest}

A series of massive revolts ravaged Northwest and Central China in the 1630 's and 1640's. The explosive spread of rebellion among peasants and military deserters in Shanxi in the drought year of 1628 , or the beginnings of a sect rebellion in Shandong from 1622 to 1624, aboriginal revolts in Sichuan and Guizhou from 1621 to 1637 , and piracy along the coasts of Taiwan and Fujian in the 1620's, are all considered to be symptomatic of

22 See Yuan, "Urban Riots and Disturbances", pp. 298-308; S. H. Wu, Communication and Imperial Control in China (Cambridge, Mass., 1970); and P. Huang, Autocracy at Work: A Study of the Yung-cheng Period, 1723-1735 (Bloomington, 1974). 
late-Ming government "paralysis", the regime's failure to keep up with its problems. Before the Manchus even invaded China and proclaimed the Qing dynasty, the Ming government collapsed. ${ }^{23}$

The current interpretation of these late-Ming peasant rebellions and the role of peasants in the Qing conquest made by historians in the People's Republic of China deflates the revolutionary nature of this class. This new assessment of the peasants' political role raises questions about whether peasant rebellions may be considered part of "class struggle" or whether peasants did indeed possess a firm class-consciousness. ${ }^{24}$ The stimulus behind this trend originated in the publication of a historical novel, $L i$ Zicheng, the first part of which came out in $1963 .{ }^{25} \mathrm{Li}$ Zicheng is the name of a rebel leader who acquired a large following in 1628 and, after holding much of North China, descended on Peking in early 1644 and proclaimed himself Emperor. Although his dynasty, the Shun, was short-lived, lasting only six weeks, he is credited with having ended Ming rule before the Manchu conquerors arrived. ${ }^{26}$ Yao Xueyin, the author of Li Zicheng, portrays $\mathrm{Li}$ as someone who did not wish to overthrow the feudal form of monarchy; indeed, Li aspired and became Empcror himself. Moreover, according to $\mathrm{Yao}, \mathrm{Li}$ was a good Confucian as well. Already in 1636, eight years before his conquest of Peking, Li had ordered the repair of a Confucian temple and was studying the Confucian classics with literati advisers, in anticipation of his Emperorship.

One leading student of PRC historiography has written: "Yao Xueyin's novel, which sold 2.3 million copies in 1977, is a good introduction" to current new trends. ${ }^{27}$ Following Yao's lead, eminent historians in the PRC

${ }^{23}$ A good review of the "traditional interpretation" of late-Ming peasant rebellions may be found in J. B. Parsons, Peasant Rebellions of the Late Ming Dynasty (Tucson, 1970). ${ }^{24}$ See Liu's excellent article "World View and Peasant Rebellion", loc. cit., for an introduction to this new historiography, especially pp. 296-303.

${ }^{25}$ An abridged English translation of this work may be found in Chinese Literature, 1978, Nos 4-8. Li Zicheng represents the minority view of certain historians writing before the Cultural Revolution (compare note 6). Further publication of the novel was suspended when authorities during the period 1966-76 ascribed the "revolutionary consciousness" of peasants to be even greater than that of the proletariat. Thus it was not until the death of Mao and the arrest of the Gang of Four in 1976 that this minority view could be heard again.

${ }^{26}$ Further information on $\mathrm{Li}$, using yeshi of "wild, unofficial histories", may be seen in $\mathrm{F}$. Wakeman's essay "The Shun Interregnum of 1644", in: From Ming to Ch'ing, pp. 39-87. Refer also to Wakeman's massive study on North China in the late Ming and early Qing, The Great Enterprise, forthcoming.

${ }^{27}$ Liu, "World View and Peasant Rebellion", p. 298. In leading Chinese journals and newspapers the present view of Chinese historical development emphasizes the forces of production, especially technology, no longer class struggle. This affirmation of the connection between the superstructure and the economic foundation reflects the current national policy preoccupation with modernization. 
have been re-appraising peasants and their role in history; for many, it is "Monarchism, hierarchy, and fatalism [which] characterize these small producers, even when they get together for rebellion."28 To protect landlords' property, to listen to hierarchically minded Confucian advisers and, worst of all, to behave like a "feudal monarch" are all characteristics of "unrevolutionary" peasant rebel leaders. Extended beyond the early Qing period, this interpretation now reigns over what was once considered China's most significant peasant movement before the Communist victory, that of the Taipings. Accordingly, even they were "tied to the Confucian or feudal world view". ${ }^{29}$

Assessing the degree of loyalist resistance to the Manchu conquest is another important topic of current research. A fundamental aspect of these analyses is the study of events and actions during the 1630's and 1640's which form the background to the loyalist movement. It is during this time that local Chinese society in various locations experimented with new kinds of political structures which ultimately affected resistance later. Paramilitary organizations, anti-bandit crop-watching corps, or professionalized police forces were founded in areas around Nanjing in the 1630 's, incorporating common people and the local elite into joint service. ${ }^{30}$ The leader of local defense in the community of Huizhou in Anhui province in 1643, a scholar by the name of Jin Sheng, who had Donglin connections, organized a new type of military unit. Instead of using only a selective group of people to engage in resistance, he led a genuine call to arms, appealing to all the peasants and public-spirited rural dwellers of Huizhou. He encouraged universal instruction in "street fighting", so that even "the women and girls [were] all capable of defending themselves and killing the bandits." 31 The area of Huizhou had previously been the scene of massive revolts by poor peasants and indentured labour directed against wealthy peasants and the local elite in the early 1630's. ${ }^{32}$ One cannot help but believe that Jin Sheng's call to popular resistance against the Manchus, however sincere, was also a way of diverting further local disruption and channelling discontent.

${ }^{28}$ Ibid., p. 300. In general, this "new" historiography subscribes to the classic Marxist view of peasants, formed from the perspective of urban and industrial Europe in the nineteenth century.

29 Ibid., pp. 301-03.

30 J. Dennerline, "Hsü Tu and the Lesson of Nanking", in: From Ming to Ch'ing, pp. 89-132.

31 Ibid., p. 110.

${ }^{32}$ See H. Zurndorfer, "Commercial Wealth and Rural Pauperism in Sixteenth Century China: Huizhou Prefecture in Transition”, forthcoming. 
In contrast, in other areas, such as Tongcheng in the same province Anhui, where local uprisings were also common in the 1630's and 1540's, the local elite could only condemn popular discontent, and when matters really became critical in 1643 , it simply fled the region..$^{33}$ Moreover, at the time of the actual conquest, the Tongcheng elite welcomed "the representatives of the Ch'ing [ . . ] as the forces of law and order [ . . ]. there was subsequently very little sign of overt loyalist resistance to the new dynasty." 34 The lack of resistance here is attributed to the weariness of the local population; years of protracted warfare and devastation had left them with the desire to return to "normal".

From a viewpoint of local response, the role of violence and political protest during these last years seemed a benefit to the traditional rural power structures as much as the Qing government. The redirecting of popular-protest drives into police-like actions or the lack of loyalist resistance are in effect two sides of the same coin. Both attitudes reaffirm the persistence of the pre-Qing rural order. The threat to local concepts of the status quo was avoided in different ways in different locales, the social structure of late-Ming society survived the violence, bloodshed and devastation, as the local elite manipulated the situation for its own wellbeing. Since the traditional rural order which reasserted itself after the Qing conquest was far beyond the direct capabilities of the new government, the solidity of this order must have been deeply entrenched, while the variation in responses to the disorders and the conquest make an easy explanation of the direction of violence and political protest for this period all the more difficult.

\section{The re-establishment of order and new forms of strife}

After the final conquest of China in the 1640's and 1650's, the Manchus turned from military matters to political affairs to ensure their reign. Obviously aware of the idea that "seizing the Empire is easy, but ruling it is difficult", the Manchus attempted and successively achieved a viable political order. Part of their success was due to the fact that their imposition of law and order moved parallel to an astonishingly effective re-assertion of non-bureaucratic law and order. The local elite once again took over its functions in ensuring efficient local administration and a secure public order. Before the first local magistrates appointed by the new dynasty had

${ }^{33}$ H. J. Beattie, “The Alternative to Resistance: The Case of T'ung-ch'eng, Anhwei”, in: From Ming to Ch'ing, pp. 239-76. A penetrating study of one of the longest resistance actions in Chinese history, occurring in Chiang-yin, is F. Wakeman, Jr, "Localism and Loyalism During the Ch'ing Conquest of Kiangnan", in: Conflict and Control, pp. 43-85.

34 Beattie, "The Alternative to Resistance", p. 256. 
arrived in provincial areas, the local elite in most locations was directing land-reclamation projects, the repairs to walls, schools and other public works, and the preparation for grain-tax collection. ${ }^{35}$ In recognition of these services, the Qing conquerors reconfirmed whatever tax exemptions this privileged group had accrued during the Ming period, and ensured the protection of their property from any violent encroachment due to local bandits or peasant resistance through control of the local militia system. ${ }^{36}$ Within a short period, no longer than ten years, order and political stability were once again re-instituted in most of China.

The exception to this development was in Southeast China, in Southern Fujian, Eastern Guangdong and Taiwan, where violence continued to dominate the tenor of life in the early Qing. A form of strife, the feud, manifested in massive armed affrays, termed xiedou in Chinese, became more problematic than ever ${ }^{37}$ The authorities considered them "private" conflicts, since neither local officials nor government installations were objects of attack, but they still thought this type of disorder was seditious and posed a threat to established order. The typical xiedou in these places would involve a group of well-endowed, land-owning families, who would fight another group of well-endowed, land-owning families. The instigators, it would seem, were quite often "good people" (liangmin), who in other locales would simply be hard-working peasants. The rural areas where these people lived were usually recently opened up, not poor, and potential excellent farming land was probably in abundance, so that the costs of these xiedou could easily be financed through clan-land investments.

The clan "armies" would cut across class lines; poor clansmen often competed for the chance to join feud bands as fighting braves (yung) or serve as "substitutes" when arrests were made of others, their expectation being a financial reward for their services. Alliances, the hiring of mercenaries and the intimidation of neutral parties were common; later, bandits,

35 One of the best studies of this topic is by a Korean historian, I Songgyu. See a translation of his work "Shantung in the Shun-chih Reign: The Establishment of Local Control and the Gentry Response", in: Ch'ing-shih Wen-t'i, IV, No 4(1980), pp. 1-34, and No 5 (1981), pp. 1-31.

36 Two case-studies on the re-establishment of tax privileges are J. Dennerline, "Fiscal Reform and Local Control: The Gentry-Bureaucratic Alliance Survives the Conquest", in: Conflict and Control, pp. 86-120, and H. J. Beattie, Land and Lineage in China: A Study of T'ung-ch'eng County, Anhwei, in the Ming and Ch'ing Dynasties (Cambridge, 1979).

37 The best study to date in English on the phenomenon of the feud in China is $\mathbf{H}$. Lamley, "Hsieh-tou: the Pathology of Violence in Southeastern China", in: Ch'ing-shih Wen-t'i, III, No 7 (1977), pp. 1-39. 
vagrants and other destitute types would join the clans in the fighting. After considerable study of this phenomenon, one author concludes that xiedou disturbances may be best described as vendetta where there is no social limitation or restraint. ${ }^{38}$ These armed feuds, on occasion, developed into internecine wars that spread over large areas of the countryside and into neighboring counties. Since most of the weapons the adherents used, including sharp-edged farm implements, knives or spears, were generally crude, xiedou affrays were pitched battles, entailing hand-to-hand combat.

The original circumstances giving vent to the feud actions were most often over local contention: land and boundary disputes, controversies over water rights, competition for control of local markets, transportation systems and labour-forces. In Taiwan, feuds featured conflicts between Chinese settlers who banded together with those who stemmed from the same mainland districts and shared dialects, religious observances and local customs in common. "Such distinctions of provenance and ethnicity set off neighboring villages from one another, and enabled rival enclaves to form among alienated communities." 39 The handling of these disturbances was not always consistent. While government troops would end these conflicts, it was necessary first for local officers to report the private conflicts, and some were reluctant to do so for fear of retaliatory accusations by the authorities. Officials were also not unknown to extract bribes and fees from both sides. In areas afflicted by xiedou disorders, nearly the entire local population became involved. Kinship ties, common-surname identities and village or territorial residence forced common inhabitants to join sides when feuds occurred.

In discussing xiedou disorder in South China, Qing authorities attributed it to the long-standing symptoms of this particular area, where harmful mercantile influences and corruption had impinged upon the local Confucian order and rural economy, and had been responsible for perpetuating unorthodox practices and frivolous life styles for a long time. This region had been part of the location of the Three Feudatories, where under the suzerainty of three feudatory princes large chunks of Guangdong and Fujian had remained outside the sphere of Qing rule until 1683.40 These areas had a great deal of experience in defense of their communities. One might suppose that this period before the Qing pacification had been a

38 Ibid.

39 Ibid., p. 11. Compare J. Meskill, A Chinese Pioneer Family: The Lins of Wu-feng, Taiwan, 1729-1895 (Princeton 1979).

${ }^{40}$ For explanation of the Three Feudatories, see L. Kessler, K'ang-hsi and the Consolidation of Ch'ing Rule (Chicago, 1976). Compare L. Struve, The Southern Ming, forthcoming. 
time when local countercultures would have arisen: customs and practices in conflict with those upheld by the authorities and maintained by society in general.

Thus, as these preliminary remarks on feud strife reveal, local areas can have their own brand of violence which has nothing to do with general Empire conditions. Clearly, Southeast China's social disorder in the Qing had deep origins in the Ming period, and one might pose, as others already have done, that the seeds of nineteenth-century discontent were laid long before, as manifested in these feuds. ${ }^{41}$

\section{Heterodoxy and the Wang Lun uprising, 1774}

Among the better-documented popular movements in the Qing period are those organized and led by religious organizations known as White Lotus sects. ${ }^{42}$ Followers searched for an "eternal and venerable mother" (Wusheng lao $\mathrm{mu}$ ), who would give birth to Maitreya, the Buddha of the third age of mankind, and thereby save it from the forces of darkness. The cry for popular rebellion against secular government occurred as a leader would try to transform the latent aspirations of adherents into explicit ones. Such millennial calls appealed to a diverse group of urban and rural folk, and took place at irregular intervals, mostly in North China in the Ming onwards. The rebellions themselves were usually short-lived; but where successful, however temporarily, they presented a serious challenge to the authorities. In October 1774 a thousand followers of a White Lotus sect leader, named Wang Lun, attacked three county seats on the North China plain in Western Shandong province, rallied several thousand other people, and occupied part of the Grand Canal city of Linqing. They held Linqing with little opposition for three weeks before being crushed by the Qing-government counter-attack.

What makes this particular protest an interesting case to study is that it occurred at a time when China was still in the midst of her Indian Summer - the period of corruption, weakness and general "decline" so well-documented from approximately 1800 onward had not yet begun. In her careful

41 Compare R. G. Groves, "Militia, Market, and Lineage: Chinese Resistance to the Occupation of Hong Kong's New Territories in 1899", in: The Journal of the Hong Kong Branch of the Royal Asiatic Society, IX (1969), pp. 31-64, and S. M. Jones and Ph. A. Kuhn, "Dynastic Decline and the Roots of Rebellion", in: The Cambridge History of China, X: Late Ch'ing, 1800-1911, Pt I, ed. by J. F. Fairbank (Cambridge, 1978), pp. 107-62.

${ }^{42}$ Hok-lan Chan, "The White Lotus Maitreya Doctrine and Popular Uprisings in Ming and Ch'ing China", in: Sinologica, X (1969), pp. 211-33; D. Overmeyer, Folk Buddhist Religion: Dissenting Sects in Late Traditional China (Cambridge, 1976). 
analysis of the Wang Lun uprising, the author of the most recent study on Wang Lun, Susan Naquin, shows that it was not a reflection of bureaucratic breakdown. ${ }^{43}$ The most obvious social, economic, political and military conditions of the era do not suggest a crisis in China at the time. Then, why this uprising in 1774 ? Naquin puts forth convincingly that the Wang Lun rebellion reflects the dynamics of its sectarian organization and millenarian beliefs rather than crises in the society itself. In other words, it would seem that this rebellion happened, when it did, because one man, Wang Lun, successfully proselytizing a millenarian ideology, was able to focus group energies and create a community which ultimately challenged the authority of the Qing State. ${ }^{44}$

Heterodoxy has long been associated with popular rebellion in Chinese history. De Groot emphasized the long Chinese tradition of firm rejection and at times ruthless persecution of heterodoxy by the State. ${ }^{45}$ The one central theme in the Chinese government's repression of heterodoxy is clear: its fear of the rise of organized forces driven by religious fanaticism, integrated by a system of leadership, supported by a mass following, and strengthened by contributions from the members, which ultimately would compete with the legitimate center of power.

There are, however, differences within heterodox movements. If a "folk religion" exists in peaceful obscurity (such as those of the Waldensians or Mennonites in Europe), its quiet sort of vitality may be eclipsed when more violent outbursts of other branches within the movement burst out. In this way, the religious context behind this particular White Lotus rebellion is important. If one sees this particular White Lotus sect disturbance as a crisis of the religion itself, as a case of the creed's inability to continue to withdraw from secular life, or its needs to argue for its own preservation with action, the reasons for Wang Lun and his followers' behaviour seem more comprehensible. Violence and political protest in this case have less to do with economic and social problems than with the dynamics of sectarian organizations and the spread of millenarian beliefs.

\section{Conclusion: Toward a typology of violence and political protest in China?}

Against a chronological perspective, this review has focused on four types of violent movements in Ming-Qing history: the urban riot, the peasant

\footnotetext{
43 S. Naquin, Shantung Rebellion (New Haven, 1981).

44 Compare similar situations in other historical civilisation in M. Adas, Prophets of Rebellion (Chapel Hill, 1979).

${ }^{45}$ J. J. M. de Groot, Sectarianism and Religious Persecution in China: A Page in the History of Religions (Leiden, 1901).
} 
rebellion, the feud, and the millenarian uprising. The question is: what do these four types of occurrences say about the development of Chinese history? If they are not part of the long stream of incidents which form part of the "dynastic cycle" or "class struggle", then how do they relate to this history? To answer that question it would seem relevant to place these events in the context of another paradigm, that of a triangular network. The visual image which emerges is that of a three-sided mobile, where each part is linked to another so that movement of any one part affects the movement of any other part. At the top sits the Emperor and below him, but tied to him and on the same level, the local elite and the populace:

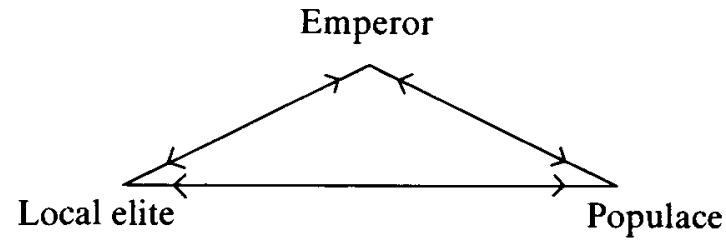

It is within this structure that these violent actions took place. In the case of the urban riot, we have seen how a segment of the local elite could team up with the populace against representatives of the Emperor. Similarly, in certain loyalist resistance movements, the local elite and the populace would strive together against a common enemy. But as the new historiography of the PRC emphasizes, the populace in political protest against the local elite would still aspire only to rule over that elite in the institution of Emperorship, and would not attempt to destroy that elite. Whatever differences the populace (and in this case, the local elite as well) had with each other, in the situation of the feud, these were not sufficiently powerful to eliminate either the leadership of the local elite on a local basis or the power of the Emperor's military control from outside. The millenarian uprising may be viewed as an ideological crisis within the populace itself and not a real trial for the power structure.

The significance of this paradigm is that it focuses on the stability of China's social and political structure. Why violence and political protest did not affect that structure rests in the fact that each corner of the triangle is bound and counterpoised by the other. The Emperor and the local elite gained their political legitimacy by their "service" to the populace; the Emperor is a moral exemplar to the populace and the local elite its guide. The local elite helped the populace, in crop-watching organizations, in directing water-conservancy projects, in building local schools. At the same time, the local elite "represented" the Emperor; it aided, informally, to collect the tax revenues from the populace for the Emperor. This structure 
weathered hundreds of years of Ming-Qing history, and began its collapse only after the institution of Emperorship was abolished in $1911 .{ }^{46}$ Once the key element in the triangle was vacated, the pull between the other two corners could no longer balance. Within forty years, the local elite became incapacitated and China's "revolutionary situation" finally experienced a "revolutionary outcome".

Neither the concept of "dynastic cycle" nor "class struggle" takes into view the constancy of this triangular structure. Concentrating on the particularities of the disturbances as opposed to the patterns of social control and the influence of cultural values, these concepts obfuscate the crucial networks which bound Chinese society into a tense but viable political order during the Ming and Qing periods. But given the amount of interest towards elaborating on this triangular paradigm, as reviewed in this essay, historians now examining Ming-Qing history should be able to integrate the studies of key events with all the more clarity in the future.

46 This event in Chinese history has been conventionally labeled the Revolution of 1911, but as Wakeman points out in The Fall of Imperial China, op. cit., pp. 225-28, the appropriateness of the word "revolution" here is questionable. 